\title{
The behavior of Brazilian companies shares return under social responsibility
}

\author{
Fernanda Bojikian Cavenaghi $^{1}$, Tabajara Pimenta Junior ${ }^{2}$, Rafael Moreira \\ Antônio33, Fabiano Guasti Lima4 ${ }^{4}$, Ana Carolina Costa Corrêa 5 \\ ${ }^{1}$ FEA-RP/USP - Universidade de São Paulo - fbcavenaghi@fearp.usp.br \\ ${ }^{2}$ FEA-RP/USP - Universidade de São Paulo - taba.jr@usp.br \\ 3 FEA-RP/USP - Universidade de São Paulo - rafaelmantonio@gmail.com \\ 4 FEA-RP/USP - Universidade de São Paulo - fgl@usp.br \\ 5 Universidade Federal de Minas Gerais - anacarolinacorrea@face.ufmg.br
}

\section{KEYWORDS}

Social responsibility, Sustainable development, Stock returns, Market value.

Received 17.04.2019 Reviewed 12.08.2019 Accepted 09.09.2019

ISSN 1980-4431 Double blind review

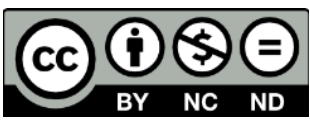

\section{ABSTRACT}

Several scientific studies seek to establish a relationship between the adoption of corporate social responsibility practices and financial and/or economic performance of companies. There are no definitive answers to this question. Compared performance of ISE - Índice de Sustentabilidade Empresarial (Index of Corporate Sustainability) and Ibovespa index, both from Brazilian stock market, is often used to characterize the influence of good business practices in this area. This work investigated this question in an innovative prism. Instead of using directly that index returns series, we constructed a portfolio composed only of companies that remained in ISE portfolio over the five years from 2012 to 2016, and compared their performance with a portfolio of an equal number of companies, taken among the most liquid ones that continuously participated in the Ibovespa portfolio in same period and which were not part of ISE. For this purpose, we used Mann-Whitney averages comparison test, return series stationarity tests - Augmented Dickey-Fuller and Phillips-Perron - and EngleGranger cointegration test. The results showed higher average returns and lower risk, measured by standard deviation, for portfolio of socially responsible companies, indicating a growth of their returns compared to portfolio of conventional companies, and also presented a tendency to balance in long term run.
PALAVRAS-CHAVE

Responsabilidade social, Desenvolvimento sustentável, Retornos de ações, Valor de mercado.
RESUMO

Vários estudos científicos procuram estabelecer uma relação entre a adoção de práticas de responsabilidade social corporativa e o desempenho financeiro e/ou econômico das empresas. Não existem respostas definitivas para esta questão. O desempenho comparado do ISE - Índice de Sustentabilidade Empresarial e do índice Ibovespa, ambos do mercado de ações brasileiro, é frequentemente utilizado para caracterizar a influência das boas práticas corporativas nesta área. Este trabalho investigou esta questão sob um prisma inovador. Em vez de usar diretamente essa série de retornos do índice, construímos um portfólio composto apenas por empresas que permaneceram na carteira ISE ao longo dos cinco anos de 2012 a 2016 e comparamos seu desempenho com uma carteira de igual número de empresas, tomadas dentre as mais líquidas que participaram continuamente do portfólio do Ibovespa no mesmo período e que não faziam parte do ISE. Para este propósito, utilizamos o teste de comparação de médias de Mann-Whitney, os testes de estacionariedade de séries de retorno - Dickey-Fuller Aumentado e Phillips-Perron - e o teste de cointegração de Engle-Granger. Os resultados mostraram maiores retornos médios e menor risco, medido pelo desviopadrão, para a carteira de empresas socialmente responsáveis, indicando um crescimento de seus ganhos comparado à carteira de empresas convencionais, e também indicaram uma tendência dos retornos em se equilibrar no longo prazo.

Revista de Negócios, v. 24, n. 3, p. 49-61, July, 2019. 


\section{Introduction}

Economic crises, social disparities, governments unable to solve their problems, globalization, increased competition and environmental problems, these are some of factors that have contributed to a greater discussion about the role of companies to society. Companies that were previously concerned only with their financial results have come under pressure from their stakeholders, that is, those that affect or are affected by company's objectives achievement such as customers, suppliers, investors, workers and government. These pressures that companies suffer can be by diffusion of reliable data, by managerial attitudes aligned with interested part demands, by fact that consumers are more and more demanding or by a socially correct posture.

There remains, at present, as argue Freguete, Nossa and Funchal (2015), a controversy about what should be the social role of companies. On the one hand, it is considered that manager responsibility is to maximize the results in favor of shareholders and owners - shareholder theory and, on the other hand, that companies promote a social action that brings benefits to society and also to its stakeholders - stakeholder theory.

For almost three decades, Drucker (1991) had foreseen that companies would play an active social role, either to supply the space not served by the government and other assistance entities or to stand out from their competitors vis-à-vis their clients and suppliers. Nowadays, shareholders know that part of their earnings is reduced by costs incurred in sustainable actions of their companies, but they understand that this decision should be part of business strategy.

Society is pressing and there is a clear tendency for companies to respect the dimensions of sustainability and social responsibility. However, there is still controversy regarding the impact of this management philosophy on the financial performance of these companies. There are several papers in the literature that seek to identify a relationship between social performance and financial performance, but the results are still contradictory. For this reason, we intended to investigate an answer to the question: Do Brazilian companies that adopt a socially responsible position show a higher return than those that do not?
The objective of this paper was to compare the performance of two portfolios, composed of Brazilian company shares, over five-year period from 2012 to 2016. One of the portfolios is composed of company shares included in ISE Índice de Sustentabilidade Empresarial (Index of Corporate Sustainability) portfolio over the entire period, and other portfolio, with an equal number of companies, is composed of most liquid company shares included in Ibovespa portfolio and which were not part of ISE. The Ibovespa is the main stock index of the Brazilian stock exchange, named B3.

\section{Theoretical Framework}

The concept of sustainability explores relationships between economic development, environmental quality, and social equity, according to Rogers, Jalal and Boyd (2007). It began to be outlined in 1972, when United Nations promoted the United Nations Conference on Human Environment, in Stockholm, Sweden. From this beginning, new visions emerged in relation to the model of economic growth based on unrestricted exploitation of natural resources. It raised awareness of issues such as environmental degradation and pollution. It also intensified, as Pereira, Silva and Carbonari (2011) observed, a search for a model capable of ensuring a balance between environmental preservation and economic development, and that satisfies current and future generation needs.

According to Sartori, Latrônico and Campos (2014), the creator of term Triple Bottom Line was Elkington (1994), for whom sustainability is a balance among three pillars: economic, social and environmental.

The central idea of sustainability, according to an economic approach, is that current decisions should not undermine future quality of life prospects. This implies that management of our economic systems must be managed from dividends of our resources.

According to a social approach, sustainable development is directly related to raising life quality of low-income people, which can be measured in terms of food, income, education, health, water supply, sanitation and only indirectly related to growth Global economy.

Sustainable development, with an emphasis on environmental aspect, is related to ecological

Revista de Negócios, v. 24, n. 3, p. 49-61, July, 2019. 
processes preservation, essential to human survival and development, to genetic diversity preservation and to sustainable use of species and ecosystems.

The concept of sustainable development, applied to business world, has become known as corporate sustainability, and can be understood as welfare progress and social justice commitment, both within internal operations of organizations and in broader social context, according to Clifton and Amran (2011).

In addition to considering traditional financial concepts, the concept of corporate sustainability also includes other factors in assessment of business wealth. According to López, Garcia and Rodriguez (2007), adoption of sustainability practices by companies aims at finding competitive advantages that allow them to achieve financial balance in management of social and environmental issues.

Corporate Social Responsibility - CSR is another important and adherent concept to sustainability. According to Carroll and Shabana (2010), the contemporary concept of CSR emerged in the late 1960s, when US executives were seeking a position on corporate responsibilities to society and in a way in which companies could deal with social problems. Davis (1960) pioneered social responsibility as decisions and actions taken by business people for reasons beyond direct economic and technical interests.

In the late 1970s, one of the most present social responsibility models in scientific literature emerged. According to Carroll (1979), a company's social responsibility encompasses economic, legal, ethical, and discretionary expectations that a society has of organizations at a given time. That is, he proposes a pyramidshaped model with four categories of responsibility ranging from base to apex.

In this pyramid, economic responsibilities are fundamental and serve as the basis for all other responsibilities. Legal responsibilities are company obligations required by laws and regulations. On the other hand, ethical responsibilities are not mandatory for organizations, but society expects them to be fulfilled, since their expectations and customs go beyond those required by law. Finally, discretionary responsibilities are not required by law or by society, giving each organization freedom to decide whether to carry them out or not (Carroll, 1979). These categories are represented by Figure 1.

Figure 1. Corporate Social Responsibility Categories

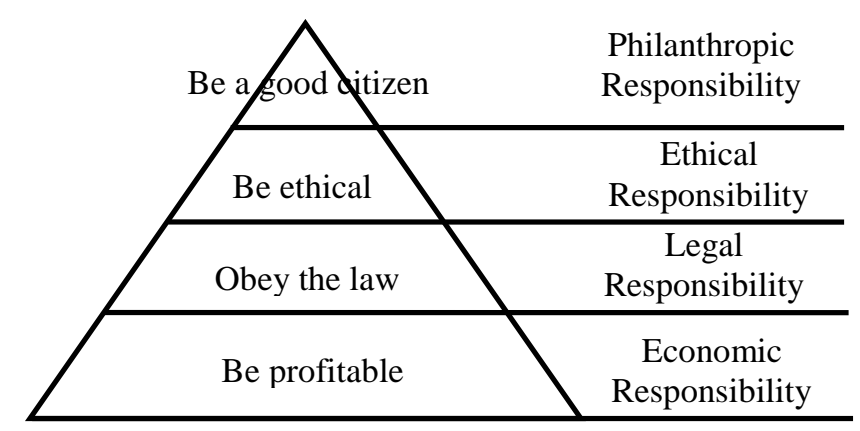

Source: Carroll (1979).

In the 1990s, an intense debate about CSR importance began in Brazil. According to Magno and Barbosa (2009), the possibility of capitalist companies engaging in social activism seemed unusual, but today it is well accepted by society due to efforts of organizations such as Grupo de Institutos, Fundações e Empresas - GIFE (Institutes, Foundations and Companies Group), Instituto Brasileiro de Análises Sociais e Econômicas - IBASE (Brazilian Institute of Social and Economic Analysis), and Instituto Ethos de Empresas e Responsabilidade Social (Ethos Institute of Business and Social Responsibility).

In Brazil, the Ethos Institute defines CSR as a management method that is established by ethical and transparent relationship of company with all stakeholders and by establishing business goals that promote society sustainable development while preserving environmental and cultural resources for future generations, respecting diversity and promoting social inequalities reduction (Ethos, 2013).

Several scientific studies have investigated the relationship between CSR and financial and/or economic performance. López et al. (2007) examined whether business performance is affected by the adoption of practices included under the term Corporate Social Responsibility. They analyzed the relation between CSR and accounting indicators and examine whether there exist significant differences in performance indicators between European firms that have adopted CSR and others that have not. For the purpose of that study, they studied 110 European companies, divided into two equally sized groups

Revista de Negócios, v. 24, n. 3, p. 49-61, July, 2019. 
with 55 companies listed on the Dow Jones Global Index (control group) and 55 listed on the Sustainability Index. Data were for period between 1998 and 2004. Results show that a short-term negative impact on performance is produced by practices of CSR.

Few years later, Byus, Deis and Ouyang (2010) replicated the paper of López et al. (2007), this time with 240 US companies and data from 1999 to 2007 period. Contrary to the first paper conclusion, they founded a better performance of companies that adopted CSR practices in relation to those that did not.

In terms of financial market indices, Campos and Lemme (2009) conducted a study based on a similar concept to CSR, called Socially Responsible Investment - SRI. They analyzed the performance of international stock exchanges indices and Brazilian equity funds, which consider environmental and social issues. The purpose of that study was to examine financial performance, under the risk and return aspects, of indexes and stock funds with the concept of SRI, comparing it with their respective benchmarks. The results indicated no statistically significant differences in risk and return between SRI indexes and portfolios examined and their benchmarks.

Much research has been done considering the Índice de Sustentabilidade Empresarial - ISE (Corporate Sustainability Index), index of the Brazilian stock market. Cavalcante, Bruni and Costa (2009), Machado, Machado and Corrar (2009), Caparelli (2010), Souza, Albuquerque, Rego and Rodrigues (2011), Pascuotte (2012), Santos, Dani, Crespi e Lavarda (2013), Martins, Bressan and Takamatsu (2015) and Dalmácio and Buoso (2016) are examples.

Cavalcante, Bruni and Costa (2009) compared the performance of a theoretical portfolio formed by the shares included in ISE index with the performance of two other theoretical portfolios that make up Ibovespa index and Brazil Index (IBrX - Índice Brasil). They found no evidence of a superior performance of the ISE portfolio in the period after its creation. However, there were indications that ISE's retroactive portfolios performed better in the period prior to the creation of the index, suggesting that pricing would have taken place prior to its official release.

Machado et al. (2009) sought to measure ISE average profitability and compare it with profitability of other indexes published that stock exchange. The quotation time series covered the period from December 2005 to November 2007. They concluded that there were no statistically consistent differences between index returns.

Caparelli (2010) found that the entry of a company into ISE portfolio causes positive accumulated abnormal returns, statistically significant, close to new portfolio announcement. This result may be more associated with positive effect of investment fund portfolios changes, portfolios that replicate ISE, rather than a positive effect on the sustainability aspect.

Souza et al. (2011) also studied the ISE index. They calculated net revenue and index return correlation, using data from 2005 to 2009 period. The results showed a high correlation.

Pascuotte (2012) analyzed whether shares of companies included in ISE portfolio had an abnormal return in the period close to inclusion report date. She analyzed data from 62 companies that entered in ISE portfolio from 2005 to 2011 period. The results showed statistically significant abnormal returns, both positive and negative.

Santos et al. (2013) analyzed the 100 largest Brazilian companies, divided into two groups, considering those that were part of the ISE portfolio and those that did not. Using logistic regression, they detected a positive relationship between corporate social reputation and economic performance measured by EVA and MVA.

Martins et al. (2015) sought to detect whether the disclosure of ISE portfolio composition, a Brazilian stock exchange index, impacts on stock returns of involved companies. They used the event study technique to capture effects of insertion or exclusion of firms in that portfolio. The results, obtained with data from 2011 to 2013 period, showed abnormal positive stock returns of companies included after index disclosure, as well as negative abnormal stock returns of excluded companies. They also verified that market adjusts new information quickly, which supports the semi-strong information efficiency hypothesis for the Brazilian capital market.

Dalmácio and Buoso (2016) have calculated performance indicators of companies that compose the ISE portfolio to compare with those of other companies listed on Brazilian stock exchange. They analyzed data for 2006 to 2012 period. The results showed that ISE companies

Revista de Negócios, v. 24, n. 3, p. 49-61, July, 2019. 
performed better than others in four indicators: stock returns; return on assets (ROA); return on equity (ROE); and debt level.

Finally, Vergini, Turra, Jacomossi and Hein (2015) analyzed social indicators and financial performance relationship of Brazilian companies listed in the Dow Jones Sustainability Index. Using panel data regression, they found evidence of a negative relationship, with no statistical consistency, between social investment and economic financial performance, considering time series of data from 2009 to 2013.

The synthesis of works in this area of knowledge, published over the last decade, reveals that, in general, there is a positive relationship between practices of social responsibility and sustainability adoption and positive results, either in stock returns or financial performance. In this group are papers of Cavalcante, Bruni and Costa (2009), Byus et al. (2010), Souza et al. (2011), Santos et al. (2013), Martins et al. (2015) and Dalmácio and Buoso (2016). However, several other studies have found conflicting results when they detect a negative relationship between such practices and financial and/or economic performance, such as López et al. (2007) and Pascuotte (2012). And there are still studies that have detected that there is no relationship between social responsibility practices and sustainability adoption and business performance, such as Campos and Lemme (2009), Machado et al. (2009) and Vergini et al. (2015). The literature review reveals, therefore, that there is no consensus on this subject, which motivates accomplishment of more researches.

\section{Methodology}

This research is classified as applied, explanatory and historical, since it seeks to solve a problem, using data from the past, without interference of researcher. It is a research with a quantitative approach, since it relies on numerical variables, measurable and treated by mathematical methods. It is further classified as longitudinal and explores secondary data.

The target population of the survey is made up of companies listed in B3, the Brazilian stock exchange, in the period of five years, from 2012 to 2016. We made the company sample selection with reference in Ibovespa quarterly theoretical portfolios, the main index of the Brazilian stock exchange, in order to consider the shares with highest levels of liquidity in that period. We examined the compositions of fifteen quarterly theoretical portfolios of Ibovespa that refers to this period, and we selected only companies with presence in all of them. This group of companies gave rise to two portfolios. One composed by the companies that composed the Corporate Sustainability Index (ISE - Índice de Sustentabilidade Empresarial, in portuguese) throughout 2012 to 2016 period. This portfolio was named Socially Responsible - SR Portfolio. And another portfolio composed of companies that did not make the ISE at any time during same period. This second portfolio was called Conventional Companies - CC Portfolio.

Once the portfolios have been defined, we have collected all historical series of daily closing prices of selected shares, with first price quotation as of the last trading session of 2011 (12/30/2011) and with last price quotation as of the last trading session of 2016 (12/30/2016), covering five full years of returns.

The proportion of each paper in the portfolio composition was based on size factor. As argued by Fama and French (1993), a three-factor model can be used to analyze the performance of stock portfolios: difference in returns relative to the market (market factor); difference in returns between stock portfolios of larger and smaller companies (size factor); and difference in returns between equity portfolios of high capitalization and low capitalization companies (value factor). So we opted for the first factor and we calculated each company Equity, multiplying the number of shares by the closing price as of 12/30/2011. We then aggregate these values in each portfolio and we consider the share of each company based on the percentage that Equity value represented in relation to total value Equity PL of portfolio.

Each of the portfolios has the same number of companies. Then, we first set up the SR Portfolio, whose number of companies determined the number of companies in the CC Portfolio, which were chosen based on hierarchy due to greater participation in Ibovespa theoretical portfolio.

After compiling the portfolios, we calculated average and cumulative returns as well as returns standard deviation for both portfolios. Portfolio returns were calculated using Equation 1.

Revista de Negócios, v. 24, n. 3, p. 49-61, July, 2019. 
[Equation 1]

$$
R_{p}=\sum_{i=1}^{n} w_{i} \cdot \bar{R}_{i}
$$

Where:

$R_{p}$ is the return on the portfolio;

$w_{i}$ is the proportion of asset $i$ in the portfolio;

$\bar{R}_{i}$ is the return on asset $\mathrm{i}$;

$n$ is the number of assets in the portfolio.

The stock returns were calculated under the continuous capitalization approach, as logarithmic returns, according to Equation 2.

$$
R_{t}=\ln \left(\frac{P_{t}}{P_{t-1}}\right)
$$

[Equation 2]

Where:

$R_{t}$ is the stock return at time t;

$P_{t}$ is the stock price at time $\mathrm{t}$;

$P_{t-1}$ is the stock price at time t-1;

The choice of logarithmic returns was an attempt to approximate the returns frequency distribution of a normal curve, which is an expected effect. Through the research planning, we aimed to apply the statistical t-Student test to compare mean returns of portfolios. This parametric test requires a normal distribution of returns and also requires that sample variances be equal to each other. For this purpose, we applied the Jarque-Bera normality test and the Levene variance homogeneity test on series of returns.

As the normality test results showed that return series did not present a normal distribution at 5\% level ( $\mathrm{p}$-value <0.05) and the Levene statistics showed that variances are not homogeneous at $5 \%$ level ( $\mathrm{p}$-value <0.05), we applied non-parametric Mann-Whitney test, which is flexible regarding variances normality and homogeneity assumptions, to compare portfolios mean returns. Mann-Whitney test is indicated to compare two unpaired groups, in order to detect whether or not they belong to same population, when t-Student test requirements are not met. Mann-Whitney test is considered a nonparametric version of the Student's t-test for independent samples.
We also followed the method used by Cavalcante et al. (2009), who tested return time series seasonality, as an alternative way, detecting returns evolution of one portfolio relative to the other. We tested the time series stationarity SR Portfolio/CC Portfolio rate at level and first difference, based on fact that, although level stationary series indicate absence of SR portfolio displacement in relation to $\mathrm{CC}$ portfolio, firstorder autoregressive series may reveal an upward or downward trend and demonstrate a shift of numerator from denominator (i.e. from the ISE to the Ibovespa).

This method, as argued by Cavalcante et al. (2009), is an interesting alternative to the technique of event study, frequently adopted. In presence of systematically positive abnormal returns, the values of SR Portfolio/CC Portfolio rate returns should express an upward trend, which can be detected by stationarity tests. On the other hand, in presence of systematically negative abnormal returns, the values SR Portfolio/CC Portfolio rate returns should express a downward trend, which can also be detected by stationarity tests.

We applied unit root tests on the series. A time series with unit root follows a random walk, and is therefore characterized as a non-stationary time series, as taught by Gujarati (2000). We applied two tests, Augmented Dickey-Fuller ADF Test - and Phillips-Perron Test - PP Test. ADF Test is based on autoregressive models, whose inclusion of lagged variables has the objective of removing any serial correlation of $t$ $\Delta \mathrm{y}$, and follows Equation 3.

$$
\Delta Y=\alpha_{0}+\gamma Y_{t-1}+\sum_{i=2}^{p} \beta_{i} \Delta Y_{t-i+1}+\varepsilon_{t}
$$

[Equation 3]

Whereas:

[Equation 4]

$$
\gamma=-\left(1-\sum_{i=1}^{p} \alpha_{i}\right)
$$

and

$$
\beta=\sum_{i=1}^{p} \alpha_{i}
$$

[Equation 5]

Where:

$\Delta Y$ is the dependent variable; 
$\alpha_{0}$ is the regression intercept;

$\gamma, \beta$ are regression coefficients;

$p$ is the autoregressive model order;

$\Delta$ is a difference operator;

$\varepsilon_{t}$ is a error structure (i.i.d.).

The analysis of ADF model - which may consider non intercept and non trend regressions, with intercept and trend, or only with intercept has a focus on $\gamma$. The null hypothesis is that $\gamma=0$, which indicates that series has a unit root and is therefore non-stationary. The $\mathrm{t}$ statistic is compared to critical Dickey-Fuller values. If $t$ is lower than the critical value, null hypothesis must be rejected, otherwise it must be accepted, indicating the series is stationary.

The Phillips-Perron Test (PP) was used to complement ADF test, as it did not depend on assumption that residue $\varepsilon_{t}$ is a white noise. This test admits the possibility of changes in intercept and slope of series, from a structural break, which ADF test cannot capture. The Phillips-Perron Test is a nonparametric model that considers the possibility of residues being autocorrelated. The Phillips-Perron model follows Equation 6 and Equations 7 and 8 give its statistic.

[Equation 6]

$$
\Delta Y=\alpha_{0}+\gamma Y_{t-1}+\varepsilon_{t}
$$

Where:

$\Delta Y$ is the dependent variable;

$\alpha_{0}$ is the regression intercept;

$\gamma$ is a regression coefficient;

$\Delta$ is a difference operator;

$\varepsilon_{t}$ is a error structure (i.i.d.).

[Equation 7]

$$
t_{P P}=\frac{s \cdot t_{b}}{\omega}-\frac{\left(\omega^{2}-s^{2}\right) \cdot T \cdot s_{b}}{2 \omega s}
$$

Whereas:

[Equation 8]

$$
\left.\omega^{2}=s+2 \sum_{j=1}^{q}\left(1-\frac{j}{q+1}\right) \cdot \frac{1}{T} \sum_{t=j+1}^{T} \varepsilon_{t} \cdot e_{t-1}\right)
$$

Where:

$t_{P P}$ is a PP Test statistic;

$t_{b}$ is a $\gamma$ parameter statistic;

$s_{b}$ is a $\gamma$ parameter standard-error;

$\omega^{2}$ is a $\sigma^{2}$ estimator, considering $\varepsilon_{t}$ heterogeneously distributed;

$T$ is the limit to $\mathrm{t}=1,2,3 \ldots, \mathrm{T}$;

$\sigma$ is regression standard-deviation;

$q$ is the number of steps;

$\varepsilon_{t}$ is a error structure (i.i.d.).

Finally, we tested a possible long-term relationship between SR and CC portfolio returns series. For this, we applied Engle and Granger Cointegration Test, Engle and Granger (1987).

If two series $\left(\mathrm{X}_{T}\right.$ and $\left.Y_{T}\right)$ are not stationary, it is possible to estimate a linear regression model given by equations 9 and 10 below.

$$
X_{T}=\beta_{1}+\beta_{2} \cdot Y_{T}+\mu_{T}^{\text {[Equation 9] }}
$$

[Equation 10]

$$
\mu_{T}=X_{T}-\beta_{1}-\beta_{2} . Y_{T}
$$

Where:

$X_{T}$ e $Y_{T}$ are time series;

$\beta_{1}$ is the regression intercept;

$\beta_{2}$ is the cointegrating parameter;

$\mu_{T}$ is the residual term.

A stationarity test applied on the residual term $\mu_{T}$ may reveal that although original series $\left(\mathrm{X}_{T}\right.$ and $\left.Y_{T}\right)$ are not stationary, a linear combination of them follows this property. That is, this linear combination of series causes a stochastic trend to cancel out, making it, as a new series, stationary. In this case, series $\mathrm{X}_{T}$ and $Y_{T}$ are called cointegrated and, as Gujarati (2000) suggests, there must be a long-term relationship between them.

\section{Analysis}

Figure 2 shows the SR and CC portfolio values evolution over 2012 to 2016 period. Values are normalized to 100 units on initial date (02/01/2012 - day/month/year). 
Figure 2. SR and CC portfolio values evolution

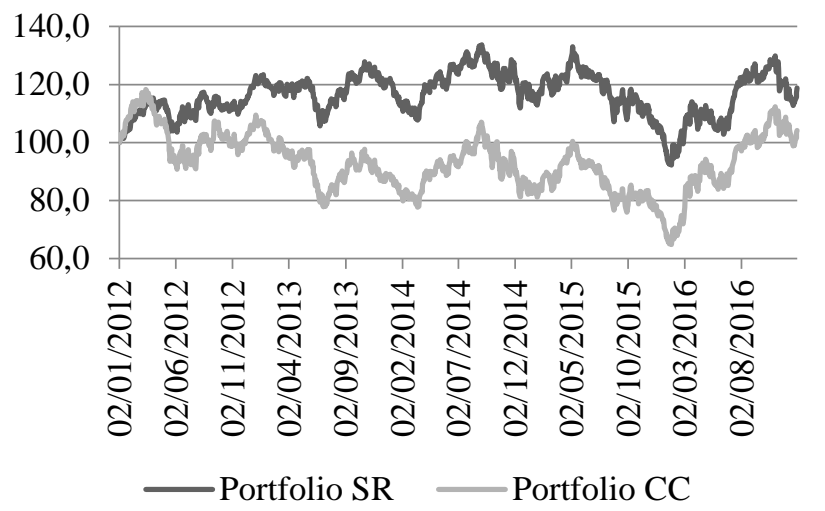

The direct observation of figure 2 reveals that the SR Portfolio performance was superior to that of CC Portfolio in this five-year period. Data presented in Table 1 confirm this observation, showing that SR Portfolio cumulative return was $18.72 \%$, while CC Portfolio cumulative return was only $4.12 \%$, sharply lower but also positive. Table 1 also shows that, according to Jarque-Bera normality test, portfolios daily returns are not normal distributed. Also, it can be observed that the homogeneity series null hypothesis of Levene test was rejected. These results have a $1 \%$ significance statistic level, and indicate that nonparametric tests should be used.

Table 1. Descriptive statistics on SR and CC portfolios returns

\begin{tabular}{lcc}
\hline & SR Portfolio & CC Portfolio \\
\hline Accumulated return & $18.72 \%$ & $4.12 \%$ \\
Average return & $0.0214 \%$ & $0.0133 \%$ \\
Maximum return & $4.54 \%$ & $6.12 \%$ \\
Minimum return & $-4.14 \%$ & $-4.91 \%$ \\
Standard deviation & $0.4831 \%$ & $0.8126 \%$ \\
Coefficient of & 22.5748 & 61.0977 \\
variation & 0.012018 & -0.012168 \\
Asymmetry & 10.23862 & 9.01254 \\
Kurtosis & $4,548.39$ & $3,224.36$ \\
Jarque-Bera Statistic & 0.00000 & 0.00000 \\
Jarque-Bera (p-value) & -30.2651 & -29.6658 \\
Levene Statistic & 0.00000 & 0.00000 \\
Levene (p-value) & 1,239 & 1,239 \\
Observations & & \\
\hline
\end{tabular}

Since the returns series distributions of both portfolios are not normal and are not homogeneous, we applied the non-parametric Mann-Whitney test to compare return means. For a $1 \%$ statistical significance level, the following hypotheses were tested:

$$
\begin{aligned}
& H_{0}: \bar{R} p_{S R}=\bar{R} p_{C C} \\
& H_{1}: \bar{R} p_{S R} \neq \bar{R} p_{C C}
\end{aligned}
$$

The null hypothesis states that there is no difference between SR Portfolio and CC Portfolio return means. The alternative hypothesis states that return means are different.

Table 2 shows Mann-Whitney Test results. As the test statistics, for both portfolios, have values less than 0.01, we rejected the null hypothesis, which indicates that the portfolios average returns are different. This result only validates statistically the expressive difference obtained by direct observation of both series returns path.

Table 2. Mann-Whitney Test results

\begin{tabular}{ccc}
\hline Estatistic & Portfolio SR & Portfolio CC \\
\hline $\begin{array}{ccc}\text { Mann-Whitney } \\
\text { U }\end{array}$ & 2245.000 & 2055.000 \\
p-value & 0.000 & 0.000 \\
\hline
\end{tabular}

This result indicates that the adoption of a socially responsible position by a company may bring superior returns for the shareholders. From this, it is possible to suggest that the market see as positive the fact that companies have sustainable practices.

Because of this, it is important to highlight the characteristics that differentiate the companies included in the socially responsible portfolio (SR) from others included in the conventional companies one (CC).

To be included in the ISE Index, in addition to the liquidity criteria, companies must meet the sustainability criteria and be selected by the deliberative council of the index (ISE, 2015).

The concept of corporate sustainability, adopted by the index, involves economic efficiency, environmental balance, social justice and corporate governance. It is based on the triple bottom line (TBL), which includes the main three dimensions - environmental, social and economic-financial - in an integrated way.

Revista de Negócios, v. 24, n. 3, p. 49-61, July, 2019. 
Consequently, companies considered committed to sustainability differentiate themselves in terms of quality, level of commitment to sustainable development, fairness, disclosure and accountability, nature of the product, besides of the business performance in the economic and financial, social, environmental and climate change dimensions (ISE, 2015).

For example, in the nature of the product dimension are considered, among others, questions regarding the possible harm and health risks to consumers and third parties caused by the use of company products or services. There is still a whole dimension about corporate governance, in order to evaluate the practices of the company in this issue.

The environmental, social, economicfinancial and climate change dimensions are assessed following the subjects: political (indicators of commitment), management (program indicators, targets and monitoring), performance and legal compliance (ISE, 2015).

It is widely discussed the importance of the social responsibility and environmental sustainability actions taken by companies for society. However, the relationship between the adoption of corporate social responsibility practices and financial and/or economic performance of companies are still under discussion.

The "stakeholder theory" defends that the firm should try to balance the interests of all the stakeholders, including maximizing at least the main of them. However, this point of view is much criticized. As pointed by Milton Friedman (1962), one of the most prominent exponents of the "shareholder theory", the main purpose of a business is to return value to its owners and to move away from it for other purposes is to expropriate shareholder value and threaten the survival of the company.

Therefore, according to the Modern Finance Theory, the main objective of a firm is to maximize the wealth of its owners, which is known as "shareholders theory". For these purpose, the companies should make their decisions based on whether they lower their cost of capital or increase their future cash flows.

Regarding the socially responsible practices in companies, it is well known that there are several difficulties associated with estimating the direct impacts of these actions on cash flows and on the cost of capital, major measures in the valuation of companies and, therefore, in their economic return.

One argument presented is that social and environmental actions represent additional costs and will tend to reduce the remuneration that could be earned by the shareholders. If it were true, sustainability best practices should be related to lower economic returns in companies.

On the other hand, the adoption of sustainability practices by companies can enhance their business value. It should have a positive impact in the economic return of them because of two main factors. First, it would contribute to the increase in their estimated future cash flows, due to the reduction of any labor and environmental liabilities, and the improvement of their competitive advantages, maintaining, for example, a better corporate image with consequent expansion of market share and prices. Second, it would contribute to the reduction of their cost of capital, due to lower levels of risks perceived by investors. For example, to illustrate Assaf Neto (2014) points that social responsibility actions can bring lower insurance costs, greater access to credit, more attractive interest rates etc.

The empirical results of this paper are in line with this second view, since there are evidences that the adoption of practices related to corporate sustainability resulted in superior economic returns to investors.

Another important finding of this research is that the socially responsible portfolio presented lower risk, measured by the standard deviation, relative to the conventional companies' one, as shown in Table 1. This added up to the fact that the SR companies had superior returns, result in a lower coefficient of variation of this portfolio (22.5748), compared to the CC one (61.0977), calculated by the ratio of the standard deviation and the mean returns. This indicator shows the amount of risk in relation to the expected return of an asset. By the Modern Portfolio Theory of Markowitz (1952), a rational and risk-averse investor should choose the investment with lower risk to the expected return offered by it. In this case, the SR portfolio had a superior performance in terms of risk and return.

Thus, investors can consider this information in the selection of assets to compose their portfolios. Furthermore, these findings have managerial implications.

Revista de Negócios, v. 24, n. 3, p. 49-61, July, 2019. 
The results suggest that by adopting a socially responsible approach, the managers would be not only meeting the interests of the stakeholders in general, bringing many benefits for the society, but also contributing to enhance the returns of the shareholders, in line with the main objective of maximizing the wealth of the owners, according by the shareholder theory.

This finding shows that following the firm's goal of maximizing owner's wealth does not mean ignoring stakeholders' interests, not adopting sustainable practices. As stated by Assaf Neto (2014), every business activity presents, in addition to its economic objectives, an ethical approach. This ethical focus ranges from seeking better returns to shareholders until respecting certain values and rights of all stakeholders. Therefore, the goal is not to maximize the welfare of these groups, but to maintain it. According to Gitman (2004), this new view does not change the goal of maximizing shareholder wealth. It is viewed as part of the corporate social responsibility. This concern is expected to generate long-term shareholder benefits by maintaining positive relationships with stakeholders.

Hawn, Chatterji and Mitchell (2018), in their financial event study, examined the reactions to sustainability in the DJSI World, the first global sustainability index. Although they discovered that investors care little about DJSI announcements, they found evidence that global assessments of sustainability are converging and that investors may increasingly be valuing continuation on the index. Thus, similarly to this research, they suggest that firms may gain some benefits from reliable sustainability activities.

Additionally, an interesting way to verify SR portfolio change over CC Portfolio during five-year period is to observe SR/CC Portfolio returns evolution. We verified a possible trend existence applying Augmented Dickey-Fuller ADF and Phillips-Perron stationarity tests. The results are shown in Table 3 and Table 4, respectively.

Table 3. Augmented Dickey-Fuller Test results

\begin{tabular}{ccccc}
\hline & ADF (0) & $\begin{array}{c}\text { p- } \\
\text { value }\end{array}$ & ADF (1) & p-value \\
\hline $\begin{array}{c}\text { SR } \\
\text { Portfolio }\end{array}$ & -2.013854 & 0.4812 & -31.22982 & 0.0000
\end{tabular}

\begin{tabular}{ccccc} 
CC & -2.398215 & 0.7796 & -33.58645 & 0.0000 \\
Portfolio & & & & \\
SR/CC & -1.005884 & 0.1865 & -18.26598 & 0.0000 \\
Portfolio & & & & \\
\hline
\end{tabular}

Table 4. Phillips-Perron Test results

\begin{tabular}{ccccc}
\hline & PP $(0)$ & p-value & PP (1) & p-value \\
\hline $\begin{array}{c}\text { SR } \\
\text { Portfolio }\end{array}$ & -2.435845 & 0.3258 & -31.10698 & 0.0000 \\
CC & -2.559871 & 0.2877 & -32.05244 & 0.0000 \\
Portfolio & & & & \\
$\begin{array}{c}\text { SR/CC } \\
\text { Portfolio }\end{array}$ & -1.326226 & 0.1672 & -17.56548 & 0.0000 \\
\hline
\end{tabular}

The results in Tables 3 and 4 show that the three time series of returns (SR Portfolio, CC Portfolio and SR/CC Portfolio) were nonstationary at the level in the period under analysis, since the $p$-value was higher than the critical value of 5\% in both the Augmented Dickey-Fuller test ADF (0) - and the Philips-Perron test - PP (0), not rejecting the null hypothesis of unit root existence. This indicates that not only the isolated series of returns of the portfolios (SR and CC), but also the combined SR/CC Portfolio series of returns presented possible upward trends in the period, which means that the average and the variance of their returns were not stable over the time.

However, when applied on first difference ADF (1) and PP (1) - tests indicate stationary series, with null hypothesis rejection, using significance level of $1 \%$ (p-value $<1 \%$ ). This result is consistent in both tests (ADF and PP) for the three series, indicating that $\mathrm{SR}, \mathrm{CC}$ and SR/CC portfolios were integrated of order one in the period. From that, it is possible to affirm that there has been a systematic shift of SR Portfolio relative to CC Portfolio over the five-year period from 2012 to 2016. Furthermore, first difference series indicate a SR/CC portfolio returns growth over time.

This means that the socially responsible portfolio presented consistently superior returns in the period compared to conventional companies' portfolio, showing a persistent long term movement. Investors may use this information in the portfolio selection of assets, as well as managers could also use it to direct their actions in practice. This is because sustainable practices can 
enhance the returns of the company, at the same time maximizing the shareholders' wealth and meeting the interests of the society, especially in the three dimensions of the triple bottom line environmental, social and economic-financial.

In order to complement the analysis, since we find that portfolio return series are not stationary at level, we performed Engle and Granger Cointegration Test, Engle and Granger (1987). Table 5 shows the results.

Table 5. Engle and Granger Cointegration Test results

\begin{tabular}{lll}
\hline & \multicolumn{2}{c}{ Residual unit root test } \\
\hline Regression $(0)$ & $\mathrm{t}-$ statistic & $\mathrm{p}$-value \\
\hline $\begin{array}{c}\mathrm{SR}=\alpha+\beta . C \mathrm{C} \\
+\varepsilon\end{array}$ & -32.16832 & 0.0000 \\
\hline
\end{tabular}

The Engle and Granger Cointegration Test results, in Table 5, indicate that the absence of cointegration null hypothesis should be rejected, with a $1 \%$ statistical reliability level (p-value < $1 \%$ ). It means that SR and CC portfolio returns series are cointegrated and, therefore, there is a long-term relationship between them. We can observe that there is a balance between average returns path, in long term, of both portfolios.

Therefore, the data suggest that the superior performance of the socially responsible portfolio presented in the period compared to the conventional companies' one tends to last in time, that is, this difference between them tends to remain in the long term run.

This is a relevant result for investors, such as fund managers, mainly those whose focus is in the long term, since they choose the assets to compose their portfolios and tend to maintain them for longer periods, compared to short term traders. Thus this kind of investors is interested in assets that are expected to have superior returns in the long term.

Durand, Paugam and Stolowy (2019), whose study replicated and expanded Hawn et al. (2018) research, found that sustainability events attract more attention from financial analysts and lead to an increase of participation of long term investors. This is an indicative of a trend that professional investors pay more attention to corporate social responsibility visible firms over time. Thus, it further corroborates the importance of the results found about the superior returns of the socially responsible companies for long term investors.

\section{Conclusion}

This study was motivated by the following question: Do Brazilian companies that adopt a socially responsible position show a higher return than those that do not? For this, we constructed two theoretical portfolios, one composed of stocks of companies that adopt corporate sustainability practices, being part of the ISE - Índice de Sustentabilidade Empresarial (Index of Corporate Sustainability) portfolio over the entire period, and another one composed by stocks of conventional companies that do not adopt such practices, composed of most liquid company shares included in Ibovespa index portfolio and which were not part of ISE - both ISE and Ibovespa are indexes of the Brazilian stock exchange, named B3. The portfolios performance was then compared.

What we could conclude, based on the results and within the research limits, is that the performance of socially responsible (SR) companies, measured by average and accumulated portfolio returns, was higher than that of conventional companies (CC), in 2012 to 2016 period. This conclusion runs counter to the conclusions of most studies on this aspect, especially Vergini et al. (2015), but it is in accordance with conclusions of the papers of Campos and Lemme (2009), and Caparelli (2010).

Therefore, the results suggest that by adopting a socially responsible approach, the managers would be not only meeting the interests of the stakeholders in general, bringing many benefits for the society, but also contributing to enhance the returns of the shareholders, in line with the main objective of maximizing the wealth of the owners, according by the shareholder theory.

It is important to highlight that the concept of corporate sustainability, adopted by the index, involves economic efficiency, environmental balance, social justice and corporate governance. It is based on the triple bottom line (TBL), which includes the main three dimensions environmental, social and economic-financial - in an integrated way. Consequently, companies considered committed to sustainability differentiate themselves in terms of quality, level

Revista de Negócios, v. 24, n. 3, p. 49-61, July, 2019. 
of commitment to sustainable development, fairness, disclosure and accountability, nature of the product, besides of the business performance in the economic and financial, social, environmental and climate change dimensions. These give indicative for the managers of sustainable practices they would adopt.

Another aspect of the findings that deserves attention is that the socially responsible portfolio presented lower risk, measured by the standard deviation, relative to the conventional companies' one. By the Modern Portfolio Theory of Markowitz (1952), a rational and risk-averse investor should choose the investment with lower risk to the expected return offered by it. In this case, the SR portfolio had a superior performance in terms of risk and return.

The stationarity tests also showed that returns of socially responsible companies' portfolio presented a positive shift from the conventional companies' portfolio, indicating that first difference of SR/CC portfolio returns growth over time. This means that the socially responsible portfolio presented consistently superior returns in the period compared to conventional companies' portfolio, indicating a persistent long term movement.

Furthermore, cointegration test indicated that returns series of both portfolios showed a long-term equilibrium relationship. Thus, the data suggest that the superior performance of the socially responsible portfolio presented in the period compared to the conventional companies' one tends to last in time. These results are in line with those obtained by Cavalcante et al. (2009).

So, in short, there is evidence that, in average, socially responsible companies presented superior returns and lower risk in the period compared to conventional companies, and this difference between them tends to remain in the long term run, indicating that would have a long term relationship between them.

Thus, investors, such as fund managers, can consider the findings of this research in the selection of assets to compose their portfolios, mainly those with long term focus.

As a suggestion for future studies we indicate a further modeling of the relationship between the socially responsible and the conventional companies' returns in order to find the type of long term relation they have.

\section{References}

Assaf Neto, A. (2014). Finanças Corporativas e Valor (7th ed.). São Paulo: Atlas.

Byus, K., Deis, D. R., \& Ouyang, B. (2010). Doing well by doing good: corporate social responsibility and profitability. SAM Advanced Management Journal, 75(1), 44-55.

Campos, F. M., \& Lemme, C. F. (2009). Investimento socialmente responsável no mercado de capitais: análise do desempenho de índices internacionais e fundos de ações brasileiros que consideram questões ambientais e sociais. Revista Eletrônica de Administração, 15(2), 286-306.

Caparelli, C. E. (2010, September). Sustentabilidade e retorno ao acionista: um evento sobre o índice de sustentabilidade empresarial. In Proceedings of XIII SEMEAD - Seminários em Administração, São Paulo, Brazil, 1-16.

Carroll, A. B. (1979). A three dimensional model of corporate performance. Academy of Management Review, 4(4), 497-505.

Carroll, A. B., \& Shabana, K. M. (2010). The Business Case for Corporate Social Responsibility: A Review of Concepts, Research and Practice. International Journal of Management Reviews, 12(1), 85-105.

Cavalcante, L. M. R. T., Bruni, A. L., \& Costa, F. J. M. (2009). Sustentabilidade empresarial e valor das ações: uma análise na bolsa de valores de São Paulo. Revista de Gestão Social e Ambiental, 3(1), 70-86.

Clifton, D., \& Amran, A. (2011). The stakeholder approach: a sustainability perspective. Journal of Business Ethics, 98(1), 121-136.

Dalmácio, F. Z., \& Buoso, D. (2016). Comparação dos indicadores contábeis das empresas com ações listadas no índice de sustentabilidade empresarial (ISE) com os das demais empresas listadas na Bovespa. Revista de Finanças e Contabilidade da Unimep, 3(2), 1-17.

Davis, K. (1960). Can business afford to ignore social responsibilities? California Management

Revista de Negócios, v. 24, n. 3, p. 49-61, July, 2019. 
Review, 2, 70-76.

Drucker, P. F. (1991). As novas realidades no governo e na política, na economia e nas empresas, na sociedade e na visão do mundo (2nd ed.). São Paulo: Pioneira.

Durand, R., Paugam, L., \& Stolowy, H. (2019). Do investors actually value sustainability indices? Replication, development, and new evidence on CSR visibility. Strategic Management Journal, 40(9), 1471-1490.

Elkington, J. (1994). Towards the sustainable corporation: win-win-win business strategies for sustainable development. California Management Review, 36(2), 90-100.

Engle, R. F., \& Granger, C. W. J. (1987). CoIntegration and Error Correction: Representation, Estimation, and Testing. Econometrica, 55(2), 251-276.

Ethos - Instituto Ethos (2013). Indicadores Ethos de responsabilidade social empresarial. São Paulo: Instituto Ethos.

Fama, E., \& French, K. (1993). Common risk factors in the returns on stocks e bonds. Journal of Financial Economics, 33, 3-56.

Freguete, L. M., Nossa, V., \& Funchal, B. (2015). Responsabilidade Social Corporativa e Desempenho Financeiro das Empresas Brasileiras na Crise de 2008. Revista de Administração Contemporânea, 19(2), 232-248.

Friedman, M. (1962). Capitalism and Freedom. Chicago, IL: University of Chicago Press.

Gitman, L. J. Princípios de Administração Financeira (10th ed.). São Paulo: Pearson Addison Wesley, 2004.

Gujarati, D. (2000) Econometria Básica. São Paulo: Makron Books.

Hawn, O., Chatterji, A. K., \& Mitchell, W. (2018). Do investors actually value sustainability? New evidence from investor reactions to the Dow Jones Sustainability Index (DJSI). Strategic Management Journal, 39(4), 949-976.
ISE (2015). Metodologia do Índice de Sustentabilidade Empresarial. BM\&FBOVESPA. Retrieved from http://www.b3.com.br/pt br/market-data-eindices/indices/indices-de-sustentabilidade/indicede-sustentabilidade-empresarial-ise.htm.

López, M. V., Garcia, A., \& Rodriguez, L. (2007). Sustainable development and corporate performance: a study based on the Dow Jones sustainability index. Journal of Business Ethics, 75(3), 285-300.

Machado, M. R., Machado, M. A. V., \& Corrar, L. J. (2009). Desempenho do índice de sustentabilidade empresarial (ISE) da bolsa de valores de São Paulo. Revista Universo Contábil, 5(2), 24-38.

Magno, A., \& Barbosa, S. (2009). O ativismo social empresarial e o seu viés antidissensual. Caderno CRH, 22(56), 325-343.

Markowitz, H. (1952). Portfolio Selection. The Journal of Finance, 7(1), 77-91.

Martins, D. L. O., Bressan, V. G. F., \& Takamatsu, R. T. (2015). Responsabilidade social e retornos das ações: uma análise de empresas listadas na BM\&FBovespa. Revista Catarinense da Ciência Contábil, 14(42), 85-98.

Pascuotte, D. (2012). Efeito no preço e volume das ações das companhias ingressantes no índice de sustentabilidade empresarial (ISE). Revista de Finanças Aplicadas, 1(1), 1-13.

Pereira, A. C., Silva, G. Z., \& Carbonari, M. E. (2011). Sustentabilidade, responsabilidade social e meio ambiente ( $1^{\text {st }}$ ed.). São Paulo: Saraiva.

Rogers, P., Jalal, K. F., \& Boyd, J. A. (2007). An introduction to sustainable development. Londres: Earthscan.

Santos, P. S. A., Dani, A. C., Crespi, N. T., \& Lavarda, C. E. F. (2013). Desempenho econômico e a responsabilidade social corporativa: uma contribuição para a análise da relação destas variáveis no caso das maiores companhias abertas Brasileiras. Enfoque: Reflexão Contábil, 32(1), 
$15-27$.

Sartori, S., Latrônico, F., \& Campos, L. M. S. (2014). Sustentabilidade e desenvolvimento sustentável: uma taxonomia no campo da literatura. Ambiente \& Sociedade, 17(1), 1-22.

Souza, F. A., Albuquerque, L. S., Rego, T. F., \& Rodrigues, M. A. (2011). Responsabilidade social empresarial: uma análise sobre a correlação entre a variação do índice de sustentabilidade empresarial (ISE) e o lucro das empresas socialmente responsáveis que compõem esse índice. Revista de Administração, Ciências Contábeis e Sustentabilidade, 1(1), 52-68.

Vergini, D. P., Turra, S., Jacomossi, F. A., \& Hein, N. (2015). Impacto da responsabilidade social no desempenho econômico financeiro das empresas brasileiras componentes do Dow Jones Sustainability Index. Revista Eletrônica em Gestão, Educação e Tecnologia Ambiental, 19(2), 879-898. 